\title{
Diabetes-Related Web Sites ${ }^{1}$
}

\author{
Linda B. Bobroff and Nancy J. Gal ${ }^{2}$
}

Managing diabetes includes learning about your disease, making positive lifestyle choices, and being a partner with your health care team. The Internet has become a major source of health information. However, finding current and reliable health information is critical to making choices that support health and avoiding potentially harmful products and practices. In general, government (.gov), educational (.edu) and recognized professional organizations (.org) Web sites provide reliable information. This fact sheet provides a list of recommended Web sites you can use to increase your knowledge, better communicate with your health care team, and make important lifestyle choices that allow you to live well with diabetes and reduce your long-term health risks.

\section{Government}

MedLine Plus/National Library of Medicine and National Institutes of Health

http://www.nlm.nih.gov/medlineplus/diabetes.html

National Center for Chronic Disease

Prevention and Health Promotion

http://www.cdc.gov/Diabetes/consumer/index.html

National Diabetes Education Program

http://www.ndep.nih.gov

National Institute of Diabetes and Digestive

and Kidney Diseases

http://www2.niddk.nih.gov/

U.S. Department of Veterans Affairs -

Diabetes Program

http://www1.va.gov/diabetes/

\section{Professional Associations}

\author{
American Association of Clinical \\ Endocrinologists \\ http://www.aace.com/
}

American Association of Diabetes Educators http://www.diabeteseducator.gov

American Diabetes Association

http://www.diabetes.org

The American Dietetic Association

http://www.eatright.org

Diabetes Research Organizations

Joslin Diabetes Center

http://www.joslin.harvard.edul

Juvenile Diabetes Research Foundation

http://www.jdrf.org

1. This document is FCS8875, one of a series of the Department of Family, Youth and Community Sciences, Florida Cooperative Extension Service, Institute of Food and Agricultural Sciences, University of Florida. First published: August 2009.

2. Linda B. Bobroff, PhD., RD, LD/N, professor, Department of Family, Youth and Community Sciences and Nancy J. Gal, M.S., Extension Agent IV, Marion County Extension; Institute of Food and Agricultural Sciences; University of Florida; Gainesville, FL 32611. 